\title{
Penentuan Tingkat Kematangan Cabe Rawit (Capsicum frutescens L.) Berdasarkan Gray Level Co-Occurrence Matrix
}

\author{
Zilvanhisna Emka Fitri \\ Jurusan Teknologi Informasi \\ Politeknik Negeri Jember \\ Jember, Indonesia \\ zilvanhisnaef@polije.ac.id \\ Arizal Mujibtamala Nanda Imron \\ Jurusan Teknik Elektro \\ Universitas Jember \\ Jember, Indonesia \\ arizal.tamala@unej.ac.id
}

\author{
Ully Nuhanatika \\ Jurusan Teknologi Informasi \\ Politeknik Negeri Jember \\ Jember, Indonesia \\ ullynuhanatika@gmail.com
}

\author{
Abdul Madjid \\ Jurusan Produksi Pertanian \\ Politeknik Negeri Jember \\ Jember, Indonesia \\ abdul_madjid@polije.ac.id
}

\begin{abstract}
The demand for cayenne pepper in Indonesia tends to increase annually, but the productivity of cayenne pepper continues to decline and depends on the changing seasons. One of the factors that must be considered in the harvest of cayenne pepper is the level of maturity. This research aims to classify the maturity level of cayenne pepper using the extraction of color and texture features. The extraction of features based on the color is taken from the mean saturation value, while the extraction of feature-based textures uses the value of the Gray Level Co-Occurrence Matrix (GLCM) feature ASM (Angular Second Moment), contrast, IDM (Inverse Difference (Entropy) and correlation (Correlation) then using angles of $0{ }^{\circ}$ and $45^{\circ}$. These features become input in the classification process using the Backpropagation method. The results of the system training are able to classify the level of maturity of cayenne pepper with an accuracy of $81.4 \%$ and an accuracy of the testing process of 74.2\%.
\end{abstract}

\section{Keywords-Cayenne pepper; GLCM;backpropagation}

Abstrak - Permintaan cabai rawit di Indonesia cenderung meningkat setiap tahunnya, namun produktivitas cabai rawit terus menurun dan bergantung pada pergantian musim. Salah satu faktor yang harus diperhatikan dalam panen cabai rawit adalah tingkat kematangan. Penelitian ini bertujuan untuk melakukan klasifikasi tingkat kematangan cabai rawit menggunakan ekstraksi fitur warna dan tekstur. Ekstraksi fitur berdasarkan warna diambil dari nilai mean saturasi, sedangkan ekstraksi fitur berdasarkan tekstur menggunakan nilai fitur Gray Level Co-occurrence Matrix (GLCM) yaitu ASM (Angular Second Moment), Kontras (Contrast), IDM (Inverse Difference Momentum), Entropi (Entropy) dan Korelasi (Correlation) dan menggunakan sudut $0^{\circ}$ dan $45^{\circ}$. Fitur-fitur tersebut menjadi masukan pada proses klasifikasi menggunakan metode Backpropagation. Hasil pelatihan sistem mampu mengklasifikasi tingkat kematangan cabai rawit dengan akurasi sebesar $81,4 \%$ dan akurasi proses pengujian cabai rawit sebesar $74,2 \%$.

\section{Keywords-cabai rawit; GLCM; backpropagation}

\section{PENDAHULUAN}

Salah satu komoditi tanaman pangan yang mempunyai peranan cukup besar untuk memenuhi kebutuhan rumah tangga dan industri pangan adalah cabai. Jumlah spesies tanaman cabai yaitu sekitar 20 spesies, namun spesies tanaman cabai yang paling banyak dibudidayakan ada 4 yaitu cabai rawit (Capsicum frutescens L.), cabai besar (Capsicum annuum L.), paprika (Capsicum annum var grossum L.) dan cabai keriting (Capsicum annuum var. Longum) [1]. Cabai rawit (Capsicum frutescens $L$.). merupakan komoditi cabai yang memiliki nilai pasar yang cukup tinggi serta menjadi kebutuhan pokok masyarakat Indonesia sehingga nilai pasar akan cabai cenderung berubah-ubah sesuai dengan musim.

Pergantian musim berpengaruh akan harga cabai rawit di pasar, pada musim kemarau produktifitas cabai rawit akan menurun namun kebutuhan pasar meningkat sehingga terjadi lonjakan harga di pasar cukup tinggi. Hal ini berakibat beberapa petani cabai berlomba-lomba memanen cabai rawit tanpa memikirkan tingkat kematangan untuk memenuhi kebutuhan pasar. Proses penentuan kematangan ini biasanya dilakukan secara manual oleh petani dengan memperhatikan warna, ukuran, bentuk dan tekstur cabai rawit. Hal ini terkadang menimbulkan kesalahan sehingga untuk meminimalisir kesalahan tersebut, maka dibutuhkan suatu teknologi dengan memanfaatkan pengolahan citra digital untuk menentukan tingkat kematangan cabai rawit.

Beberapa penelitian terkait pengolahan citra digital cabai telah dilakukan yaitu Sistem Identifikasi Citra Jenis Cabai (Capsicum annuum L.) menggunakan metode Klasifikasi City Block Distance. Pada penelitian tersebut, data yang digunakan sebagai standart referensi sebanyak 5 sampel untuk masing-masing jenis cabai yaitu cabai besar, cabai rawit, cabai keriting dan paprika. Kemudian dilakukan variasi ukuran citra menggunakan metode matrix jarak. Hasil pengujian sistem identifikasi citra cabai menunjukkan tingkat akurasi yang tinggi sebesar $93 \%$ pada ukuran citra cabai 10x10 dengan menggunakan metode Klasifikasi Lorentzian Distance dan paling rendah tingkat akurasinya adalah 57\% pada ukuran citra cabai 20x15 dengan menggunakan metode Klasifikasi Gower Distance [1]. Penelitian selanjutnya yaitu implementasi metode klasifikasi naïve bayes untuk memprediksi kualitas cabai. Pada penelitian tersebut kualitas cabai ditentukan menjadi 4 kelas yaitu kualitas A cabai merah berukuran besar, kualitas B cabai hijau berukuran besar, kualitas $\mathrm{C}$ cabai merah berukuran kecil dan kualitas D cabai hijau berukuran kecil. Parameter yang digunakan 
adalah jumlah tangkai, persentase tangkai, nilai komponen red, jumlah piksel red, nilai komponen green, jumlah piksel green, nilai komponen blue dan jumlah piksel blue. Metode naïve bayes mampu mengklasifikasikan kualitas cabai dengan tingkat akurasi 93,33\%[2]. Penelitian selanjutnya tentang Klasifikasi Kualitas Tanaman Cabai Menggunakan Metode Fuzzy K-Nearest Neighbor (FKNN), namun pada penelitian ini cabai yang digunakan pada penelitian adalah cabai merah besar dengan dua kelas yaitu layak jual dan belum layak jual[3]. Penelitian lanjutan yaitu Aplikasi Pengolahan Citra Kematangan Cabai Kathur dengan Metode K-Nearest Neighbor dengan teknik pengolahan citra yang dilakukan terdiri dari operasi sharping untuk proses penajaman citra, konversi warna ke ruang warna grayscale dan deteksi tepi menggunakan operator kirsch serta metode klasifikasi yang digunakan adalah KNN dengan akurasi sebesar 60\%[4]. Penelitian dikembangkan dengan mengklasifikasi cabai berdasarkan fitur HSV citra dimana terdapat empat kelas cabai yaitu cabai mentah, setengah matang, matang dan busuk. Pada tiap kelas, diambil fitur warna yaitu komponen Hue, Saturation dan Value kemudian fitur tersebut menjadi input pada metode klasifikasi Fuzzy KNearest Neighbor dengan tingat akurasi sebesar 86,66\%[5].

Selain penelitian diatas beberapa penelitian yang juga menjadi rujukan peneliti yaitu Identifikasi Kematangan Buah Apel dengan Gray Level Co-Occurrence Matrix (GLCM) dapat mengenali 12 data latih dan 7 data uji dengan kriteria mengkal, mentah dan matang[6]. Ekstraksi fitur menggunakan metode GLCM juga digunakan dalam penelitian Otomatisasi Klasifikasi Kematangan Buah Mengkudu dengan tingkat akurasi sebesar 87,22\%. Metode klasifikasi lain yang mampu mengklasifikasi mutu buah dengan tingkat akurasi yang tinggi yaitu metode Backpropagation. Metode tersebut mampu mengklasifikasi mutu buah pisang dengan tingkat akurasi sebesar 94\%[7].Metode backpropagation juga diterapkan pada penelitian untuk mengklasifikasi tingkat kematangan mangga podang dengan tingkat akurasi sebesar $100 \%$.

Berdasarkan uraian beberapa penelitian diatas menjadi rujukan bagi penulis dalam mengembangkan penelitian tingkat kematangan cabai rawit selanjutnya. Penelitian ini dilakukan dengan mengklasifikasi tingkat kematangan cabai rawit secara otomatis. Data yang digunakan terdiri dari 4 kelas yaitu cabai rawit merah matang, cabai rawit orange matang, cabai rawit hijau tua matang dan cabai rawit tidak matang. Salah satu pengembangan yang dilakukan adalah dengan menambahkan fitur tekstur dari Gray Level CoOccurrence Matrix (GLCM) dan menggunakan metode klasifikasi Backpropagation untuk menentukan tingkat kematangan cabai rawit.

\section{METODE PENELITIAN}

Pengambilan sampel penelitian ini dilaksanakan di Desa Brambang Darussalam, Kecamatan Tlogosari, Kabupaten Bondowoso. Teknik pengolahan citra digital yang digunakan terdiri dari beberapa tahapan yaitu :

1. Pengambilan citra cabai rawit.

2. Proses preprocessing yaitu proses konversi warna.

3. Pengambilan proses ekstraksi fitur.

4. Proses klasifikasi pada 4 kelas yaitu cabai rawit matang merah, cabai rawit matang orange, cabai rawit matang hijau tua dan cabai rawit tidak matanga.
Alur prosedural tahapan penelitian ditunjukkan pada Gambar 1. Citra sampel cabai rawit yang didapatkan dari proses pengambilan gambar dengan jarak $10 \mathrm{~cm}$ dari kamera digital. Proses preprocessing citra diawali dengan melakukan proses cropping citra dari ukuran 3120 × 3120 piksel menjadi 501 x 1401 piksel. Hal tersebut dilakukan agar proses komputasi menjadi lebih cepat. Variasi sampel cabai rawit yang digunakan yaitu matang merah, matang orange, matang hijau tua dan tidak matang, variasi citra cabe rawit ditunjukkan pada Gambar 2

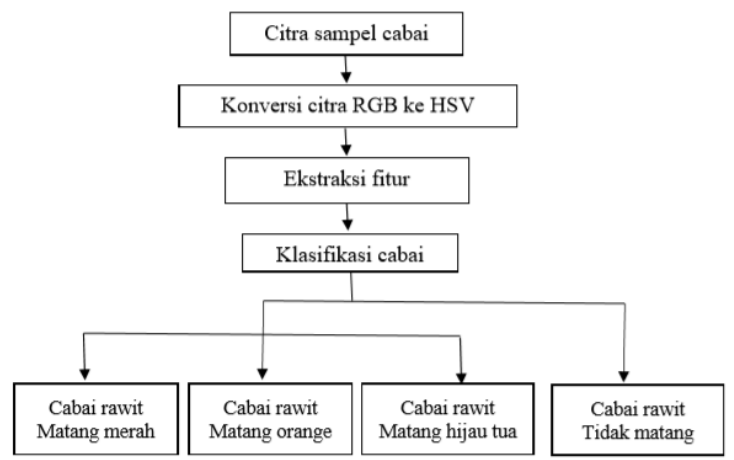

Fig. 1. Diagram blok teknik penentuan kematangan cabai rawit.
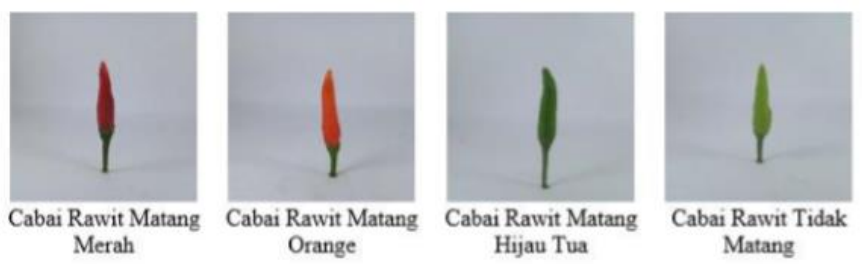

Fig. 2. Variasi cabai rawit

Citra asli biasanya dengan format ruang warna RGB, citra cabai rawit dipecah dan ditampilkan pada masingmasing komponen. Contohnya citra cabai rawit matang merah dipecah dan ditampilkan pada komponen red, green dan blue seperti yang terlihat pada Gambar 3. Gambar 3 menunjukkan bahwa dari 3 komponen tersebut belum merepresentasikan obyek yang diteliti karena apabila citra diganti dengan kelas matang orange, matang hijau tua dan tidak matang citra hasil komponen berbeda. Selain itu citra RGB mempunyai kelemahan yaitu sulit disegmentasi karena ruang warnanya terlalu besar. Oleh karena itu citra RGB perlu dikonversi ke ruang warna lain, contohnya pada ruang warna HSV.

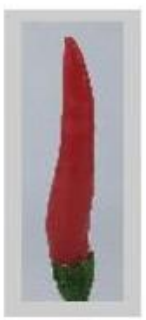

(a)

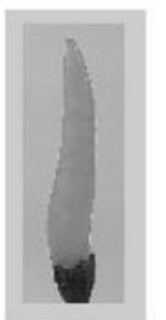

(b)

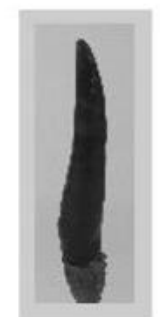

(c)

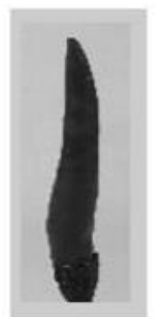

(d)
Fig. 3. (a) Citra asli, (b) Citra komponen red, (c) Citra komponen green dan (d) Citra komponen blue

Gambar 3 menunjukkan bahwa dari 3 komponen tersebut belum merepresentasikan obyek yang diteliti karena apabila citra diganti dengan kelas matang orange, matang 
hijau tua dan tidak matang citra hasil komponen berbeda. Selain itu citra RGB mempunyai kelemahan yaitu sulit disegmentasi karena ruang warnanya terlalu besar. Oleh karena itu citra RGB perlu dikonversi ke ruang warna lain, contohnya pada ruang warna HSV. HSV (Hue Saturation Value) merupakan suatu ruang warna yang modelnya dekat dengan model penglihatan mata manusia. Proses konversi warna dari RGB ke HSV berdasarkan persamaan rumus [8] :

$$
\begin{gathered}
H=\tan \left(\frac{3(G-B)}{(R-G)+(R-B)}\right) \\
S=1-\frac{\min (R, G, B)}{V} \\
V=\frac{\mathrm{R}+\mathrm{G}+\mathrm{B}}{3}
\end{gathered}
$$

Setelah dilakukan proses konversi ke HSV, citra warna HSV tersebut dipisah dan ditampilkan tiap komponennya sehingga didapatkan citra komponen Hue, citra komponen Saturasi dan citra komponen Value seperti pada Gambar 4.
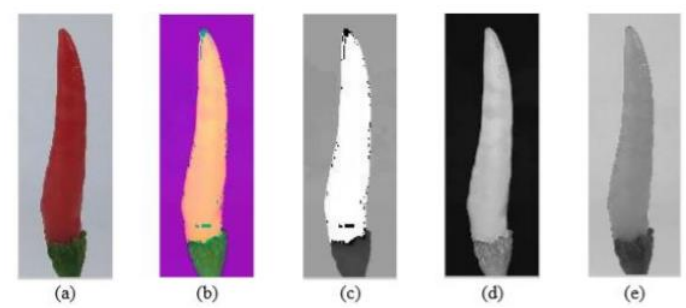

Fig. 4. (a) Citra asli, (b) Citra HSV, (c) Citra komponen H, (d) Citra komponen S dan (e) Citra komponen V

Gambar 4 dilakukan proses analisis citra yang lebih merepresentasikan obyek yang diteliti dan didapatkan bahwa citra komponen Saturasi. Saturasi merupakan salah satu elemen warna HSV yang mewakili tingkat intensitas warna san memiliki rentang antara 0 dan 1 . Langkah selanjutnya, citra saturasi tersebut dilakukan proses pengambilan ekstraksi fitur warna dan tekstur. Ekstraksi fitur warna diambil berdasarkan nilai mean saturasi citra, sedangkan ekstraksi fitur tekstur diambil menggunakan fitur Gray Level Co-Occurrence Matrix (GLCM) yang dinilai paling efektif [9]. GLCM adalah matriks derajat keabuan yang merepresentasikan hubungan suatu derajat keabuan dengan derajat keabuan lain. Matriks tersebut merepresentasikan frekuensi munculnya dua piksel dengan intensitas tertentu dalam jarak $\mathrm{d}$ dan arah sudut $\theta$ tertentu. Oleh karena itu, matriks memberikan informasi berbeda yang diperoleh dari perbedaan jarak antar piksel[10].

Langkah pertama menghitung fitur GLCM yaitu mengubah citra RGB menjadi citra berskala (citra grayscale) kemudian tentukan komposisi piksel dan lakukan jumlah pasangan piksel seperti Gambar 5. Langkah kedua yaitu menciptakan matriks co-occurrence dengan matriks transposenya, kemudian dilakukan normalisasi terhadap matriks simetris dengan menghitung probabilitas setiap elemen matriks seperti Gambar 6. Langkah terakhir yaitu menghitung fitur GLCM dimana tiap fitur dihitung dengan satu piksel jarak di dua arah sudut yaitu $0^{\circ}$ dan $45^{\circ}$ untuk mendeteksi co-occurence[11].
Contoh Perhitungan dengan Arah $0^{\circ}$

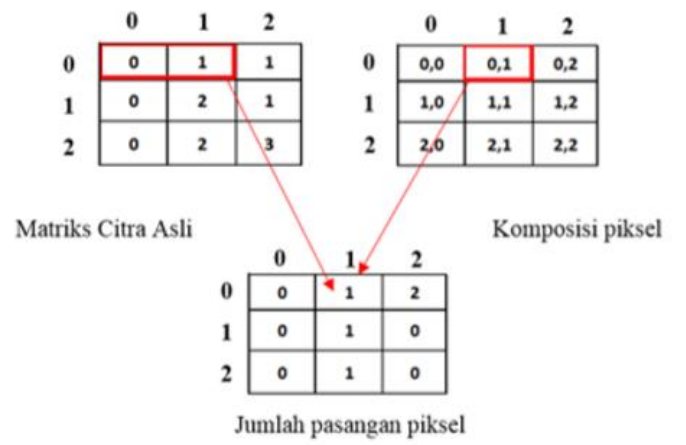

Fig. 5. Penentuan awal matriks GLCM berdasarkan pasangan dua piksel[12].

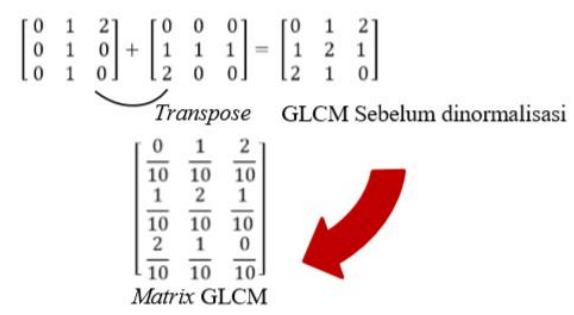

Fig. 6. Proses pembentukan matriks GLCM yang simetris[12].

Terdapat 5 fitur tekstur yang digunakan berdasarkan persamaan rumus [8] :

$$
A S M=\sum_{i=1}^{L} \sum_{j=1}^{L} P_{i, j}^{2}
$$

$$
\begin{gathered}
\text { CONTRAST }=\sum_{n=1}^{L} n^{2}\left(\sum_{|i-j|=n} P_{(i, j)}\right) \\
I D M=\sum_{i=1}^{L} \sum_{j=1}^{L} \frac{P_{(i, j)}}{1+(i-j)^{2}}
\end{gathered}
$$

$$
\text { ENTROPY }=\sum_{i=1}^{L} \sum_{j=1}^{L} P_{(i, j)} \log \left(P_{(i, j)}\right)
$$

Correlation $=\frac{\sum_{i=1}^{L} \sum_{j=1}^{L}\left(i-\mu_{i^{\prime}}\right)\left(j-\mu_{j^{\prime}}\right)\left(P_{(i, j)}\right)}{\sqrt{\sigma_{i}^{2} \sigma_{j}^{2}}}$

Angular Second Moment (ASM) merepresentasikan nilai tertinggi saat piksel-piksel tersebut homogen. Sementara nilai kontras merepresentasikan variasi antar derajat keabuan suatu daerah. Nilai Invers Different Moment (IDM) merepresentasikan kesamaan nilai keabuan antar piksel. Nilai entropi merepresentasikan ketidakteraturan ukuran bentuk. Serta nilai korelasi merepresentasikan tingkat abuabu ketergantungan linier antara piksel pada posisi tertentu terhadap piksel lain[13].

Terdapat 10 parameter fitur tekstur yang ditunjukkan pada Tabel 1 dan 2 . Total fitur yang digunakan adalah 11 
parameter dan parameter tersebut menjadi input dari metode klasifikasi backpropagation.

Table 1. Nilai fitur GLCM dengan sudut $0^{\circ}$

\begin{tabular}{|l|r|r|r|r|c|}
\hline \multirow{2}{*}{ Kelas } & \multicolumn{5}{|c|}{ Fitur Tekstur } \\
\cline { 2 - 6 } & GO ASM & $\begin{array}{c}\text { GO } \\
\text { Kontras }\end{array}$ & G0 IDM & $\begin{array}{c}\text { G0 } \\
\text { Entropi }\end{array}$ & $\begin{array}{c}\text { G0 } \\
\text { Korelasi }\end{array}$ \\
\hline $\begin{array}{l}\text { Matang } \\
\text { Merah }\end{array}$ & 0,1161 & 26,5852 & 0,7583 & 4,6497 & 0,00015 \\
\hline $\begin{array}{l}\text { Matang } \\
\text { Orange }\end{array}$ & 0,1144 & 26,0846 & 0,7702 & 4,5736 & 0,00012 \\
\hline $\begin{array}{l}\text { Matang } \\
\text { Hijau Tua }\end{array}$ & 0,1534 & 28,4891 & 0,7118 & 4,6714 & 0,00015 \\
\hline $\begin{array}{l}\text { Tidak } \\
\text { Matang }\end{array}$ & 0,1103 & 13,3265 & 0,7213 & 4,7634 & 0,00021 \\
\hline
\end{tabular}

Table 2. Nilai fitur GLCM dengan sudut $45^{\circ}$

\begin{tabular}{|l|c|c|c|c|c|}
\hline \multirow{2}{*}{ Kelas } & \multicolumn{5}{|c|}{ Fitur Tekstur } \\
\cline { 2 - 6 } & $\begin{array}{c}\text { G45 } \\
\text { ASM }\end{array}$ & $\begin{array}{c}\text { G45 } \\
\text { Kontras }\end{array}$ & $\begin{array}{c}\text { G45 } \\
\text { IDM }\end{array}$ & $\begin{array}{c}\text { G45 } \\
\text { Entropi }\end{array}$ & $\begin{array}{c}\text { G45 } \\
\text { Korelasi }\end{array}$ \\
\hline $\begin{array}{l}\text { Matang } \\
\text { Merah }\end{array}$ & 0,1133 & 36,5842 & 0,7173 & 4,7832 & 0,00015 \\
\hline $\begin{array}{l}\text { Matang } \\
\text { Orange }\end{array}$ & 0,1122 & 33,8419 & 0,7315 & 4,7162 & 0,00012 \\
\hline $\begin{array}{l}\text { Matang } \\
\text { Hijau Tua }\end{array}$ & 0,1504 & 41,1547 & 0,6764 & 4,8158 & 0,00015 \\
\hline $\begin{array}{l}\text { Tidak } \\
\text { Matang }\end{array}$ & 0,1079 & 17,5809 & 0,6791 & 4,9118 & 0,00021 \\
\hline
\end{tabular}

Backpropagation merupakan salah satu algoritma jaringan syaraf tiruan supervised learning yang memiliki arsitektur jaringan dengan input sebanyak $\mathrm{n}$ ditambah dengan satu bias dan sebuah atau lebih layer tersembunyi[14]. Secara umum arsitektur jaringan syaraf tiruan metode Backpropagation ditunjukkan pada Gambar 5.

Dari gambar tersebut dijelaskan bahwa $\mathrm{V}_{\mathrm{ji}}$ adalah bobot garis dari unit masukan $\mathrm{X}_{\mathrm{i}}$ ke unit layar tersembunyi $\mathrm{Z}_{\mathrm{j}}\left(\mathrm{V}_{\mathrm{J} 0}\right.$ adalah bobot garis yang menghubungkan bias di unit masukan ke unit layer tersembunyi $\mathrm{Z}_{\mathrm{j}}$ ). Sedangkan $\mathrm{W}_{\mathrm{kj}}$ adalah bobot dari unit layer tersembunyi $\mathrm{Z}_{\mathrm{j}}$ ke unit keluaran $\mathrm{Y}_{\mathrm{k}}\left(\mathrm{W}_{\mathrm{k} 0}\right.$ adalah bobot dari bias di layar tersembunyi ke unit keluaran $Y_{k}$ ). Sedangkan Algoritma jaringan syaraf tiruan backpropagation ditunjukkan pada Gambar 6 .

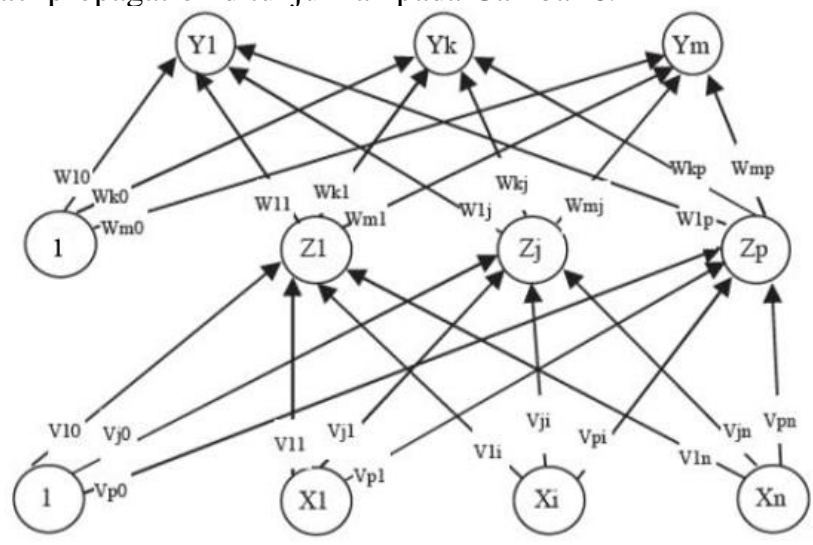

Fig. 7. Arsitektur jaringan syaraf tiruan backpropagation

Pada penelitian ini digunakan 280 data untuk proses pelatihan (training) dan 120 data untuk proses pengujian (testing). Jumlah neuron hidden layer yang digunakan berjumlah 6 . Kelas input data dibagi menjadi 11 input yang terdiri dari parameter saturasi, G0 ASM, G0 kontras, G0 IDM, G0 entropi, G0 korelasi, G45 ASM, G45 kontras, G45 IDM, G45 entropi dan G45 korelasi. Sedangkan kelas output dibagi menjadi 4 kelas yaitu matang merah, matang orange, matang hijau tua dan tidak matang

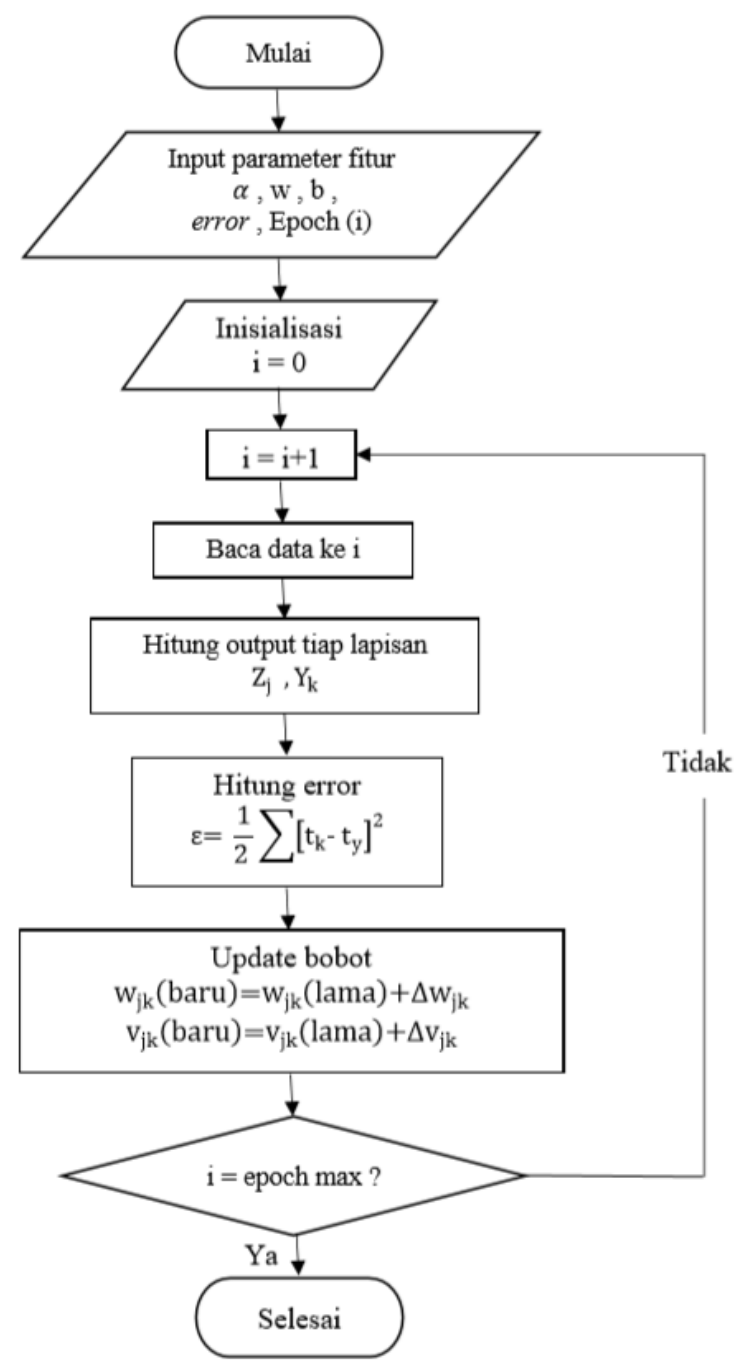

Fig. 5. Algoritma metode backpropagation

\section{HASIL DAN PEMBAHASAN}

Pada penelitian ini terdapat perbedaan dengan penelitian yang berjudul Fuzzy K-Nearest Neighbor pada Klasifikasi Kematangan Cabai Berdasarkan Fitur HSV Citra. Pada penelitian tersebut, data yang digunakan terdiri dari empat kelas yaitu data cabai rawit mentah, cabai rawit setengah matang, cabai rawit matang dan cabai rawit busuk. Selain itu pada data penelitian tersebut tidak menampilkan tangkai cabai. Sedangkan pada penelitian ini data yang digunakan cabai rawit beserta tangkainya seperti pada Gambar 2. Hal ini tentu akan berpengaruh pada proses pengolahan citra dan nilai dari ekstraksi fitur. Nilai fitur GLCM yang diambil dipengaruhi oleh nilai keabuan dari tangkai cabai rawit sehingga saat pengambilan data sebaiknya tidak disertai dengan tangkai cabai agar tidak menjadi noise pada citra cabai rawit.

Pada sistem klasifikasi, penentuan laju pembelajaran (learning rate $\alpha$ ) sangat berpengaruh pada hasil akurasi. Pada penelitian ini dilakukan variasi nilai $\alpha$ yaitu $0.1,0.3$ dan 0.9 yang hasil persentase akurasinya ditunjukkan pada Tabel 3. 
Table 3. Presentase akurasi berdasarkan variasi $\alpha$

\begin{tabular}{|c|c|}
\hline Nilai $\boldsymbol{\alpha}$ & Hasil presentase akurasi \\
\hline 0,1 & $81,4 \%$ \\
\hline 0,3 & $70,3 \%$ \\
\hline 0,9 & $47,1 \%$ \\
\hline
\end{tabular}

Pada Tabel 3 disimpulkan bahwa ketika menggunakan learning rate sebesar 0,1 diperoleh tingkat akurasi terbaik sistem yaitu $81,4 \%$. Nilai epoch yang diperoleh adalah 500000 dan error 0,001. Untuk persentase akurasi training dalam mengklasifikasi tingkat kematangan cabe rawit dapat dilihat pada Tabel 4.

Table 4. Hasil akurasi data training pada 4 kelas
\begin{tabular}{|l|c|c|c|}
\hline \multicolumn{1}{|c|}{ Kelas } & Data Benar & Data Salah & $\begin{array}{c}\text { Persentase } \\
\text { kebenaran }\end{array}$ \\
\hline Matang merah & 60 & 10 & $85,71 \%$ \\
\hline Matang orange & 54 & 16 & $77,14 \%$ \\
\hline Matang Hijau Tua & 35 & 35 & $50 \%$ \\
\hline Tidak Matang & 53 & 17 & 75,71 \\
\hline
\end{tabular}

Tabel 4 menunjukkan bahwa pada proses training atau pelatihan data, sistem mampu mengenali dan mengklasifikasi cabai rawit dengan benar pada kelas matang merah sebesar $85.71 \%$ sedangkan sistem kesulitan mengenali dan mengklasifikasi cabai rawit kelas matang hijau tua dengan akurat sebesar $50 \%$. Proses selanjutnya yaitu proses testing data, dimana sistem yang telah dilakukan proses pelatihan tersebut diuji dengan data citra lain yang berjumlah 30 pada masing-masing kelas. Akurasi terbaik proses testing sebesar $74,2 \%$, hasil tersebut terbilang cukup baik sehingga dilakukan analisis sistem dalam mengenali masing-masing kelas untuk mengetahui akurasi sistemnya seperti yang ditunjukkan pada Tabel 5.

Table 5. Hasil akurasi data testing pada 4 kelas

\begin{tabular}{|l|c|c|c|}
\hline \multicolumn{1}{|c|}{ Kelas } & Data Benar & Data Salah & $\begin{array}{c}\text { Persentase } \\
\text { kebenaran }\end{array}$ \\
\hline Matang merah & 25 & 5 & $83,3 \%$ \\
\hline Matang orange & 23 & 7 & $76,6 \%$ \\
\hline Matang Hijau Tua & 21 & 9 & $70 \%$ \\
\hline Tidak Matang & 20 & 10 & $66,6 \%$ \\
\hline
\end{tabular}

Tabel 5 menunjukkan bahwa sistem mampu mengenali dan mengklasifikasi cabai rawit dengan akurasi yaitu cabai rawit kelas matang merah $83,3 \%$, cabai rawit kelas matang orange $76,6 \%$, cabai rawit kelas matang hijau tua $70 \%$ dan cabai rawit kelas tidak matang 66.6\%. Dari hasil analisis tersebut, masih ditemukannya ketidakcocokan antara cabai rawit matang dan cabai rawit tidak matang.

\section{KESIMPULAN}

Berdasarkan penjelasan diatas, sistem dengan metode klasifikasi Backpropagation mampu mengenali dan menentukan tingkat kematangan cabai rawit dengan akurasi training sebesar $81.4 \%$, sementara akurasi testing sebesar
74,2\%. Hal ini terjadi karena masih adanya beberapa parameter dari kelas matang merah, matang orange, matang hijau tua dan tidak matang yang nilainya berdekatan dengan kelas yang lain. Contohnya pada Tabel 1, nilai parameter G0 ASM dan G0 kontras pada kelas matang merah dan rawit memiliki nilai yang berdekatan. Contoh lain pada Tabel 2, pada parameter G45 IDM nilai kelas matang hijau tua memiliki kedekatan nilai dengan kelas tidak matang sehingga hal tersebut memungkinkan untuk sistem dalam melakukan proses training maupun testing salah mengenali keempat kelas tersebut. Maka diperlukan penelitian lanjutan dengan memperhatikan pengambilan citra cabai rawit tanpa menggunakan batangnya serta melakuan perbaikan pada parameter atau metode klasifikasi yang digunakan.

\section{REFERENSI}

[1] N. T. Anggraeni and A. Fadlil, "SISTEM IDENTIFIKASI CITRA JENIS CABAI (Capsicum Annum,” vol. 1, p. 10, 2013.

[2] A. Ghofur, "IMPLEMENTASI METODE KLASIFIKASI NAIVE BAYES UNTUK MEMPREDIKSI KUALITAS CABAI," vol. 1, no. 1, p. 7, 2016

[3] A. A. Indra Wiratmaka, I. F. Rozi, and R. A. Asmara, "KLASIFIKASI KUALITAS TANAMAN CABAI MENGGUNAKAN METODE FUZZY K-NEAREST NEIGHBOR (FKNN)," J. Inform. Polinema, vol. 3, no. 3, p. 1, Mar. 2017, doi: 10.33795/jip.v3i3.25.

[4] M. S. Muttaqin, "Aplikasi Pengolahan Citra Kematangan Cabai Kathur dengan Metode K-Nearest Neighbor," Simki-Techsain, vol. 01, no. 04, p. 10, 2017.

[5] F. Liantoni and F. N. Annisa, "FUZZY K-NEAREST NEIGHBOR PADA KLASIFIKASI KEMATANGAN CABAI BERDASARKAN FITUR HSV CITRA," JIPI J. Ilm. Penelit. Dan Pembelajaran Inform., vol. 3, no. 2, Dec. 2018, doi: 10.29100/jipi.v3i2.851.

[6] M. Widyaningsih, "Identifikasi Kematangan Buah Apel Dengan Gray Level Co-Occurrence Matrix (GLCM)," J. SAINTEKOM, vol. 6, no. 1, p. 71, Mar. 2017, doi: 10.33020/saintekom.v6i1.7.

[7] Y. P. Wiharja and A. Harjoko, "Pemrosesan Citra Digital untuk Klasifikasi Mutu Buah Pisang Menggunakan Jaringan Saraf Tiruan," vol. 4 , no. 1 , p. $12,2014$.

[8] D. Putra, Pengolahan Citra Digital, I. Yogyakarta: PENERBIT ANDI, 2010.

[9] F. Wibowo and A. Harjoko, "Klasifikasi Mutu Pepaya Berdasarkan Ciri Tekstur GLCM Menggunakan Jaringan Saraf Tiruan,” Khazanah Inform. J. Ilmu Komput. Dan Inform., vol. 3, no. 2, p. 100, Jan. 2018, doi: $10.23917 /$ khif.v3i2.4516.

[10] F. Roberti de Siqueira, W. Robson Schwartz, and H. Pedrini, "Multiscale gray level co-occurrence matrices for texture description," Neurocomputing, vol. 120, pp. 336-345, Nov. 2013, doi: 10.1016/j.neucom.2012.09.042.

[11] H. Wijayanto, "KLASIFIKASI BATIK MENGGUNAKAN METODE K-NEAREST NEIGHBOUR BERDASARKAN GRAY LEVEL CO-OCCURRENCE MATRICES (GLCM)," p. 6.

[12] Z. E. Fitri, "Klasifikasi Trombosit Pada Citra Hapusan Darah Tepi Berdasarkan Gray Level Co-Occurrence Matrix Menggunakan Backpropagation," Institut Teknologi Sepuluh Nopember, Surabaya, 2017

[13] S. F. Kusuma, R. E. Pawening, and R. Dijaya, "Otomatisasi klasifikasi kematangan buah mengkudu berdasarkan warna dan tekstur," Regist. J. Ilm. Teknol. Sist. Inf., vol. 3, no. 1, p. 17, Jan. 2017, doi: 10.26594/register.v3i1.576.

[14] A. Sudarsono, "JARINGAN SYARAF TIRUAN UNTUK MEMPREDIKSI LAJU PERTUMBUHAN PENDUDUK MENGGUNAKAN METODE BACPROPAGATION (STUDI KASUS DI KOTA BENGKULU)," vol. 12, no. 1, p. 9, 2016. 